\title{
PESANTREN DAN RELIGIOUS AUTHORITATIVE PARENTING: Studi Kasus Sistem Wali Asuh di Pondok Pesantren Nurul Jadid
}

\author{
Achmad Fawaid \\ Universitas Nurul Jadid, Probolinggo, Indonesia \\ fawaidachmad@gmail.com \\ Uswatun Hasanah \\ Universitas Nurul Jadid, Probolinggo, Indonesia \\ uswatunhasanahook@gmail.com \\ Diterima 05 Februari 2020 | Direview 27 April 2020 | Diterbitkan 30 Juni 2020

\begin{abstract}
:
The caring rights in the pesantren change to a guardianship who is then demanded to understand all aspects of the developments and control the Islamic students's activities, so that it runs effectively. This research is about how the parenting system is implemented in the Az-Zainiyah area of the Nurul Jadid Islamic Boarding School. The data collection is done by interview and observation techniques. The results showed several important points in the parenting system in pesantren. First, the guardianship plays an important role as a substitute for parents while in the pesantren. Second, the adoption of a parenting system as a form of educational praxis in pesantren. Third, the performance of guardianship requires more attention from all parties, both from students who act as guardianship, boarding schools that are required to provide direction and guidance in terms of caring for students and caregivers who control and provide solutions for the existence of guradianship's programe. The implication of this study is that any Islamic student who is given responsibility in terms of care requires need a good enough strategy to realize the vision and mission of the pesantren.
\end{abstract}

Keywords: Guardian, System, Pesantren.

Abstrak:

Hak kepengasuban di pesantren berganti pada seorang wali asub yang kemudian dituntut untuk memahami selurub aspek perkembangan dan mengontrol kegiatan santri agar berjalan secara efektif. Studi ini meneliti bagaimana sistem pola asub yang diterapkan dalam lingkup wilayah Az-Zainiyah Pondok Pesantren Nurul Jadid. Adapun pengumpulan data dilakukan dengan teknik. wawancara dan observasi. Hasil penelitian menunjukkan beberapa poin penting dalam sistem pola asub di pesantren. Pertama, wali asub berperan penting sebagai pengganti orang tua selama berada di pesantren. Kedua, penerapan sistem pola asuh sebagai bentuk praksis pendidikan dalam pesantren. Ketiga, kinerja wali asub memerlukan perbatian lebih dari semua pibak, baik dari santri yang berperan sebagai wali asuh, pesantren yang dibaruskan memberi arahan dan bimbingan dalam bal kepengasuhan santri dan juga jajaran pengasub yang mengontrol dan memberikan solusi bagi adanya program wali asuh. Implikasi dari studi ini adalah siapapun santri yang diberi tanggung jawab dalam hal pengasuban, memerlukan strategi yang cukup baik untuk. mewujudkan visi dan misi pesantren.

Kata Kunci: Wali asuh, Sistem, Pesantren

\section{Pendahuluan}

Anak merupakan anugerah yang diberikan Allah pada kedua orang tuanya. Kehadiran anak menjadi suatu amanah yang harus dipertanggung jawabkan. Selain merawat dan membesarkan, orang tua juga berkewajiban untuk memberi pendidikan yang layak agar anak memahami hakikat manusia sebagai hamba yang harus beriman serta bertaqwa kepada tuhan yang maha Esa ${ }^{1}$. Pendidikan merupakan suatu usaha sadar dan terencana untuk mencapai dan mengasah potensi yang ada dalam diri anak. Tujuan pendidikan tidak hanya sebagai transfer ilmu, melainkan juga sarana untuk menghargai nilai-nilai yang tertanam dalam spiritual dan kemanusian serta peningkatan moral kemanusiaan ${ }^{2}$.

${ }^{1}$ Chusnul Muali, "Rasionalitas Konsepsi Budaya Nusantara dalam Menggagas Pendidikan Karakter Bangsa Multikultural", Jurnal Islam Nusantara 1, no. 1 (2017), 105-117.

2Zamakhsyari Dhofier, Tradisi Pesantren: Studi Pandangan Hidup Kyai dan Visinya Mengenai Masa Depan Indonesi, (Jakarta: LP3ES, 2015), 65

DOI: $10.18592 /$ jiiu.v\%ovi\%i.3484 
Pendidikan merupakan kebutuhan manusia untuk melanjutkan kehidupan di masa depan, sehingga kedudukan pendidikan menjadi suatu hal yang urgen dalam mengantarkan manusia menjadi seseorang yang berkualitas, bermoral dan mampu bersosial dengan baik terhadap lingkungannya. ${ }^{3}$ Dibalik suatu sistem pendidikan, tidak akan terlepas dari cara orang tua mendidik dan mengasuh anak. pola asuh orang tua dalam mengasuh, menjaga, merawat dan mendidik anak menjadi hal yang sangat mempengaruhi perkembangan dan pertumbuhan anak. Konsistensi orang tua dalam menjaga dan membimbing anak sangat dibutuhkan hingga anak beranjak pada usia remaja.

Kajian pola asuh yang dilakukan baik dalam perspektif Islam ataupun psikologi sudah banyak diperbincangkan. Hasilnya, terdapat macam pola asuh yang kurang mencapai target bagaimana menciptakan seorang anak yang mampu menjadi generasi yang berkualitas. Banyak dari kajian pola asuh yang masih belum berjalan sesuai konteks perkembangan zaman dan berdasarkan ajaran agama. ${ }^{4}$ Dalam penerapan pola asuh yang baik, orang tua perlu memberikan kasih sayang serta bersikap positif kepada anak, agar sifat dan sikap tersebut menjadi cermin bagi anak untuk memiliki konsep diri yang positif dalam menilai diri sendiri. Tujuan daripada pola asuh ialah membangun ikatan emosional antara anak dengan orang tua serta membimbing seorang anak agar dapat beradaptasi dengan baik terhadap lingkungan sosialnya. ${ }^{5}$

Pola asuh yang dilakukan orang tua juga sangat berperan dan menentukan dasar pendidikan sekaligus perkembangan anak. Dewasa ini, tidak semua orang tua memiliki waktu yang cukup untuk mengasuh anak dikarenakan beberapa alasan sehingga tidak sedikit orang tua menitipkan anaknya di pesantren karena orang tua lebih percaya sistem pola asuh yang ada didalamnya. Anggapan masyarakat tentang pesantren sebagai tempat atau bengkel untuk memperbaiki seseorang menandakan lekatnya pola kedisiplinan yang sangat tinggi didalamnya. Hal tersebut dibuktikan dengan adanya peraturan-peraturan sekaligus hukuman yang diberlakukan sesuai dengan jenis pelanggarannya. Pola pikir tersebut terjadi karena adanya pembentukan karakter santri yang dibangun melalui pola asuh yang dilakukan di pesantren.

Pesantren merupakan aset budaya asli Indonesia yang menjadi salah satu lembaga pendidikan Islam tertua yang memiliki visi misi untuk mendidik, membina, mengasuh serta membimbing anak untuk menjadi manusia yang memiliki keimanan dan ketaqwaan yang tinggi, memiliki karakter luhur (akblaq al-karimah), penguasaan ilmu dan tekhnologi sehingga anak mampu mengembangkan potensi baik dalam dirinya. ${ }^{6}$

Sebagaimana dalam lingkungan keluarga, lingkungan pesantren kemudian menjadi suatu lingkungan yang sangat berperan penting bagi para santri dalam membentuk karakter. Kendati demikian, pola asuh yang ada di lingkungan pesantren

${ }^{3}$ Asiatik, Abdul Hamid, \& Chusnul. "Smart Parenting Demokratis Dalam Membangun karakter Anak". Al-Athfal Jurna Pendidikan Anak. 4, no.1 (2017): 1-16

"Amalina Rizqi, "Hubungan Pola Asub Pondok Pesantren dengan Pembentukan Karakter Santriwati (Studi Kasus di Pondok Pesantren Ta'mirul Isalam Surakarta)", (Skripsi Program Sarjana Pendidikan, Institut Agama Islam Negeri Salatiga, 2016), 4

${ }^{5}$ Muallifah, Psycho Islamic Smart Parenting, (Jogjakarta: Deva Press, 2009), 41

${ }^{6}$ Rafiqatul Hamidiyah Lubis, "Metode Parenting Pembentukan Sikap di Pondok Pesantren Modern Darussalam Kepahiang, Bengkulu”, (Skripisi Program Sarjana Sosial, Institut Agama Islam Negeri Bengkulu, 2018), 33. 
harus mempunyai sistem yang cukup baik dalam mengarahkan dan membimbing para santri.

Pola asuh yang terdapat di pesantren dengan beragam karakter anak atau santri mempengaruhi perkembangan psikis santri. Pesantren menjadikan seorang pengurus sebagai seorang pengasuh yang membantu dan membimbing para santri dalam membentuk pribadi atau karakter yang lebih baik serta memiliki kemandirian yang kuat. Sebagai wakil dari seorang pemangku pesantren atau yang biasa disebut dengan kyai, pengurus memiliki tantangan berat dimana pengurus dituntut untuk mampu mengetahui beberapa karakter dari beberapa santri agar bisa membantu mencapai target tertentu. Semisal dalam memberi pemahaman kepada santri tentang bagaimana layaknya seorang santri dituntut untuk selalu berakhlak karimah kepada yang lain. ${ }^{7}$

Terkait pembahasan pola asuh yang berada di pesantren, Pondok Pesantren Nurul Jadid, Probolinggo, memiliki sistem yang disebut dengan istilah wali asuh. Program wali asuh ini muncul sebagai ciri khas yang melekat di Pondok Pesantren Nurul Jadid dalam menangani dan membina santri yang terbilang cukup banyak. Dalam penerapannya, program wali asuh tersebut fokus pada pembinaan dan pembimbingan yang dilakukan selama $24 \mathrm{jam}$. Hal tersebut dimaksudkan agar seluruh santri memiliki pengganti dari orang tua yang mampu mengarahkan dan membantunya dalam memecahkan masalah, membimbingnya menjadi insan yang memiliki kepribadian baik serta mengarahkan santri menjadi manusia yang berintelektual tinggi.

Pesantren Nurul jadid memiliki slogan trilogi santri dan panca kesadaran santri, hal tersebut memicu pihak pesantren untuk meningkatkan kualitas santri menjadi manusia paripurna. Untuk menjadi manusia yang benar-benar memiliki kualitas positif syarat utamanya ialah beriman yang benar dan memiliki akidah yang kuat. ${ }^{8}$ Dari itu, untuk mewujudkan hal tersebut santri membutuhkan pendampingan yang intensif dalam berbagai hal yang berkaitan dengan pengembangan potensi yang ada dalam dirinya.

Berawal dari hal tersebut diatas, maka kajian ini berfokus pada sistem kewaliasuhan yang terdapat di lingkungan Pesantren Nurul Jadid, Karanganyar, Paiton, Probolinggo. Hal tersebut menarik untuk diteliti karena tatanan dalam pola kewaliasuhan cukup memberi dampak yang signifikan terhadap pembentukan karakter santri dan pencapaian tujuan dari visi misi pesantren.

Penelitian yang dilakukan menggunakan jenis penelitian deskripstif dengan pendekatan kualitatif, untuk teknik pengumpulan data menggunakan wawancara dan observasi. Terkait informan dalam penelitian ini adalah ketua BK/WA (Bimbingan dan Konseling/Wali Asuh) dan sejumlah wali asuh yang berada di wilayah Az-Zainiyah Pondok Pesantren Nurul Jadid. Alasan memilih informan adalah untuk mengetahui bagaimana sistem wali asuh serta penerapannya di Pondok Pesantren Nurul Jadid. Sedangkan untuk teknik dalam observasi dilakukan untuk mengamati sacara langsung maupun tidak langsung terkait perilaku dan perkembangan santri.

\section{Pesantren dan Pola Asuh}

Akar sejarah didirikannya sebuah pesantren berawal dari adanya tuntutan dan kebutuhan zaman. Perjalanan sejarah pesantren terlahir dan tumbuh atas dasar kesadaran dan kewajiban untuk menyebarkan ajaran agama Islam sekaligus melahirkan

${ }^{7}$ Hasan Baharun, "Total Moral Quality: A New Approach for Character Education in Pesantren", Jurnal Ulumuna 21, no. 1 (2017), 57-80.

${ }^{8}$ Dhofir Zuhry, Peradaban Santri, (Jakarta: PT. Gramedia, 2019), 183. 
kader-kader penerus ulama' dalam meneruskan sebuah perjuangan. ${ }^{9}$ Pada umumnya, pesantren berawal dari sosok kyai di suatu tempat yang kemudian didatangi oleh santri yang ingin menuntut ilmu agama kepadanya. Kemudian, setelah semakin banyak santri yang ingin menimba ilmu kepada kyai, timbullah inisiatif seorang kyai untuk mendirikan sebuah lembaga yang disebut dengan pesantren.

Pesantren sebagai institusionalisasi atau pelembagaan dari model pendidikan tradisional tidak diragukan lagi keberhasilannya dalam mendidik seorang santri. Sebagai lembaga yang merupakan budaya asli Indonesia, eksistensi sebuah pesantren sudah teruji keberadaannya dengan tetap dan berkembangnya lembaga pesantren meski dengan berbagai terpaan transformasi zaman. ${ }^{10}$ Menurut penelitian yang dilakukan oleh Manfred Ziemek, peniliti pendidikan Islam asal Jerman, mengutip temuan UNESCO tercatat sebanyak 53.077 pesantren diseluruh penjuru Indonesia pada tahun 1954. Namun, data terbaru yang dilakukan oleh Pusat Pengembangan Penelitian dan Pendidikan Pelatihan (P-5) Kementrian Agama tercatat ada 28.000 pesantren yang tersebar luas di 33 provinsi diseluruh Indonesia dengan jumlah santri mencapai 3,85 juta jiwa. ${ }^{11}$ Catatan tersebut membuktikan bahwa pesantren memiliki eksistensi yang kuat dengan selalu mengevaluasi dan membenahi sistem yang ada didalamnya agar dapat berkembang dengan baik. ${ }^{12}$

Keberadaan pesantren yang tetap kokoh sebagai lembaga yang memiliki kepercayaan lebih dari masyarakat, menuntut pesantren untuk selalu konsisten terhadap tiga fungsi utamanya, yakni: Pertama, pesantren sebagai ladang untuk menumbuhkan dan mencetak calon-calon muballigh dan pemikir agama. Setiap santri yang menuntut ilmu di pesantren menjadi calon penerus para kyai dan ulama dalam penyebaran agama Islam di masa mendatang. Kedua, Sebagai lembaga yang mampu mewujudkan adanya sumber daya manusia (SDM) yang cukup berkualitas. Keilmuan yang berada di dalam pesantren tidak hanya mengkaji ilmu tentang khazanah keislaman, pesantren juga memberikan pengetahuan formal dan tekhnologi guna mewujudkan manusia yang berkembang dan tumbuh sesuai tantangan zaman. Ketiga, sebagai lembaga yang tidak hanya mengelola sistem pendidikan, melainkan juga memberikan sumbangsih dan pemberdayaan kepada masyarakat. ${ }^{13}$

Pesantren sudah sejak dahulu menjadi lembaga pendidikan yang banyak memiliki kekayaan tradisional. Ditengah arusnya perkembangan zaman, pesantren membutuhkan penguatan dasar-dasar metodelogi pendidikan dan pembenahan sistem agar tetap memiliki eksistensi kuat di tengah masyarakat sebagai lembaga pendidikan yang mampu membentuk santri yang memiliki pribadi luhur dan berintelektual tinggi. Akan tetapi dalam pembenahannya, pesantren harus tetap menjaga tradisi lama dengan tidak menolak wawasan baru sebagai wacana dalam mengembangkan pendidikan pesantren sesuai dengan perkembangan zaman.

Melihat perkembangan dalam poros kehidupan pesantren, terdapat dua macam pergeseran yang dilihat dari perjalanan sejarah pesantren. a) Pergeseran fungsi, yakni

${ }^{9}$ Hasbullah, Sejarah Pendidikan Islam di Indonesia, (Jakarta: LKIS, 1999), 47

${ }^{10}$ Zulhimma, "Dinamika Perkembangan Pondok Pesantren di Indonesia", Darul 'Ilmi 1, no. 2, (2013)

${ }^{11}$ Dhofir Zuhry, Peradaban Santri, 159

${ }^{12}$ Alfi Najmatil, Hamid, Chusnul, "Urgensi Keterlibatan Wali Asuh Dalam Dinamikan Pendidikan di Pesantren", Journal of Islam Education Studies, 6, no. 1, (2018), 2527-4511

${ }^{13}$ Sekretariat PP Nurul Jadid. 2019. Selayang Pandang Pondok Pesantren Nurul Jadid. Paiton: Bagian Humas dan Protokuler Sekretariat Pondok Pesantren Nurul Jadid. 
pesantren yang awalnya berdiri sebagai sarana dakwah agama dan transfer ilmu agama, maka selanjutnya berganti sebagai pusat pengembangan masyarakat (fungsi social dan pelestarian lingkungan hidup). b) Pergesaran sistem manajemen, dimana yang pada awalnya sistem manajemen tunggal (satu orang kyai) menjadi sistem kepemimpinan kolektif. Hal ini menjadi perbaikan sistem karena berbagai kebijakan diambil berdasarkan hasil pemikiran bersama ${ }^{14}$.

Bentuk lingkungan sebuah pesantren memiliki keunikan dan ciri khas tersendiri. Ciri khas sebuah pesantren tercermin dari adanya hubungan antara santri dan kyai yang disertai keta'dzimannya, kesederhanaan dan kemandirian hidup, adanya gotong royong dengan penuh persaudaraan serta terlatihnya hidup disiplin dan terikat. Lembaga yang mengadopsi sistem pendidikan dua puluh empat jam dalam mengkondisikan santri menjadikan pesantren sebagai lembaga yang bermutu dan terjamin. ${ }^{15}$

Berbicara terkait pesantren, seorang kyai menjadi elemen yang paling esensial di dalamnya, karena erat kaitannya dengan sebuah peran yang sangat mempengaruhi pertumbuhan sebuah pesantren dengan bekal kemampuan pribadi yang dimilikinya. Seorang kyai mempunyai kemampuan untuk menyebar luaskan pengetahuan dan khazanah keislaman, hal tersebut menjadi ranah ketokohannya yang sangat istimewa. Kyai akan sangat disegani dan kharismatik apabila mampu menjadi uswah hasanah atau teladan baik bagi para santri ataupun masyarakat umum. ${ }^{16}$ Istilah kyai dipakai oleh masyarakat jawa untuk menyebut seseorang yang mempunyai kharisma dan umumnya mempunyai sebuah pesantren, mengajarkan kitab-kitab klasik dan memiliki keterikatan dengan Islam tradisional. ${ }^{17}$ Kyai dalam kehidupan sosial-kemasyarakatan sebagai penyiar agama Ilahi dan pewaris para Nabi. Untuk itu, kyai kerap kali menjadi rujukan atau referensi masyarakat dalam memberi keputusan dan tindakan sosial. Dalam penyebaran agama, kyai memiliki mobilitas yang tinggi dalam mempertahankan ajaran yang dibawa oleh Rasul, melihat perannya sebagai pewaris para Nabi.

Tidak hanya mengenai kedudukan kyai dalam masyarakat, dalam pesantren peran kyai lebih memiliki eksistensi sebagai pimpinan dari suatu lembaga pendidikan. Kyai sebagai titik pusat teladan bagi para santri memiliki peran dalam mengasuh, mendidik, melayani, mengayomi dan mencerdaskan para santri. Namun, hal tersebut tidak memungkinkan bagi seorang kyai untuk langsung terjun dan turun tangan sendiri dalam mengotrol setiap kegiatan para santri. Maka, kyai menjadikan santri senior sebagai pengganti atau wakil dalam mengurus seluruh kebutuhan santri.

Dalam melayani santri mengembangkan potensi yang ada dalam dirinya, pendidikan pesantren memiliki sistem yang cukup baik. Pendidikan yang dilakukan selama kurun waktu dua puluh empat jam mempengaruhi hasil pencapaian target visi misi pesantren. Hal tersebut tidak lepas dari pola asuh yang diberlakukan kepada santri dalam membimbing, mendidik, mengarahkan dan membina. Kemudian, parenting pesantren menjadi istilah untuk pola asuh yang ada didalam pesantren.

${ }^{14}$ Abuddin Nata, Sejarah Pertumbuhan dan Perkembangan Lembaga-Lembaga Pendidikan Islam di Indonesia, ( Jakarta: Grasindo, 2001), 158

${ }^{15} \mathrm{Akmal}$ Mundiri, Afidatul Bariroh, "Trans Internalisasi Pembentukan Karakter Melalui Trilogi Santri dan Panca Kesandaran Santri”, IQRA‘ (Jurnal Kajian Ilmu Pendidikan), 3, no.1, (2018), 24-55

${ }^{16}$ Dhofir Zuhry, Peradaban Santri, 64

${ }^{17}$ Zamakhsyari Dhofier, Tradisi Pesantren: Studi Pandangan Hidup Kyai dan Visinya Mengenai Masa Depan Indonesi, 94 
Parenting merupakan suatu proses mengasah keterampilan dalam mengasuh anak yang memiliki landasan beberapa aturan yang mulia. Pola asuh sebagai salah satu proses dalam merawat dan memelihara anak menggunakan teknik dan metode yang cenderung menitik beratkan kasih sayang dan ketulusan cinta yang mendalam dari orang tua. ${ }^{18}$ Le Vine dalam Lestari mengurai tujuan daripada parenting meliputi: petama, memperhatikan aspek perkembangan dan kesehatan fisik; kedua, memaksimalkan kapasitas perilaku dalam menjaga diri; ketiga, optimalisasi pengembangan nilai-nilai budaya. Tujuan tersebut tidak lain sebagai suatu usaha untuk mewujudkan kualitas perkembangan anak dan mengasah potensi baik yang ada dalam diri anak. ${ }^{19}$

Pola parenting menjadi bahan rujukan yang sangat ideal, karena hal tersebut menjadi strategi yang cukup baik dalam memberikan pelayanan pendidikan secara mandiri untuk anak sebagai pembentukan karakter baik dan kepribadian yang luhur. ${ }^{20}$ Sementara itu, pola parenting dalam lingkungan keluarga memiliki beberapa jenis, diantaranya: (1) Otoriter, orang tua cenderung berperan sebagai pengendali, pengawas, dan selalu memaksakan apa yang menjadi kehendak sendiri daripada menuruti kehendak anak. Anak yang dibesarkan melalui sistem pola asuh ini, biasanya anak akan bersikap tenang, tidak suka melawan, tidak agresif dan mempunyai perilaku yang baik. Namun, tidak semua anak dapat diberikan pola asuh seperti ini, karena terkadang hal tersebut justru menjadikan hubungan antara anak dan orang tua menjadi cenderung akan renggang dan berpotensi lebih antagonistik (berlawanan). (2) Demokratis, pola asuh ini lebih terarah pada keputusan dan kepentingan bersama, dibandingkan orang tua hanya mementingkan keinginan anak secara personal. Hal yang demikian, menjadikan anak mudah bergaul, ramah dan aktif, sehingga anak bisa belajar menerima dengan bijak persepsi ataupun pendapat orang lain. (3) Permisif, pola asuh yang mendidik anak secara lebih bebas, dimana anak dianggap sudah seperti orang dewasa. Orang tua menganggap semua kegiatan yang dilakukan anak benar dan sudah tidak memerlukan bimbingan. Hal tersebut, menjadikan anak memiliki sifat nakal, lemah, manja dan bahkan mudah membenci karena menganggap dirinya tidak diperhatikan dan kurang tanggung jawab. ${ }^{21}$ Implementasi dari tiga jenis pola parenting membutuhkan pemahaman karakter dari masing-masing anak. Agar dalam persoalan mendidik dan mengasuh anak, orang tua dapat menyesuaikan karakter anak dengan pola pengasuhan yang ada. Sehingga, anak mampu mengembangkan potensi dirinya secara baik dan optimal.

Dari beberapa jenis pola asuh yang ada, pola asuh otoritatif atau demokratis sangat cocok untuk diterapkan dalam lingkungan pesantren. Pola asuh tersebut cenderung lebih bersikap rasional, realistis terhadap kemampuan anak dan tidak mengharap lebih dari kemampuan anak. ${ }^{22}$ Pola asuh otoritatif berfungsi dalam

\footnotetext{
${ }^{18}$ Muhammad Takdir Ilahi, Quantum Parenting, (Jogjakarta: Ar-Ruzz Media, 2013), 133.

${ }^{19}$ Sri Lestari, PSIKOLOGI KELUARG A: Penanaman Nilai Dan Penanganan Konflik Dalam Keluarga, (Jakarta: Prenamedia Group, 2012), 36.

${ }^{20}$ Hasan Baharun and Rohmatul Ummah, "Strengthening Student's Character in Akhlaq Subject Through Problem Based Learning Model”. Tadris: Jurnal Keguruan Dan Ilmu Tarbiyah 3, no. 1 (2018), 2130 .

${ }^{21}$ Saiful Bahri Djamarah, Pola Asub Orang tua dan Komunikasi dalam Keluarga upaya membangun Citra Membentuk Pribadi Anak, (Jakarta: Rineka Cipta, 2014), 50

${ }^{22 N u r ~ H i d a y a t, ~ A s m u j i, ~ \& ~ W a l i d . ~ " H u b u n g a n ~ P o l a ~ A s u h ~ W a l i ~ K a m a r ~ D e n g a n ~ T i n g k a t ~}$ Kemandirian Adl (Activity Of Daily Living) Santri Usia Sekolah Di Pondok Pesantren Anak-Anak Dan Tahfidzul Qur'an Al-Qodiri Jember", http://fikes.unmuhjember.ac.id, (diakses 17 Desember 2019).
} 
membentuk karakter santri yang lebih mandiri, karena dalam satu penelitian dikemukakan bahwa anak (santri) yang diasuh dengan pola otoritatif cenderung akan melakukan negoisasi dan diskusi bersama ketika akan memutuskan suatu pendapat. ${ }^{23}$ Oleh karena itu, pola asuh tersebut membantu anak untuk lebih bersikap mandiri, dengan tidak melepas kontrol serta pemantauan terhadap kegiatan yang dilakukan oleh santri.

Beralih pada pola asuh yang ada dalam pesantren, jajaran pengasuh memanfaatkan santri senior untuk menjadi pengurus sebagai pengganti dari peran kyai yang kemudian memegang alih kepengasuhan dari orang tua. Seorang pengurus diberi beban tanggung jawab dalam membimbing, mendidik, membina dan mengarahkan para santri sebagaimana tugas dan tanggung jawab orang tua. Tugas menjaga santri junior selama 24 jam bertujuan untuk mewujudkan santri yang mempunyai pribadi luhur dan kuat serta siap berkecimpung sepenuhnya dengan lingkungan dan masyarakat. ${ }^{24}$

Sebagai seorang pengurus yang menjadi tangan kanan dari pengasuh pesantren untuk mengasuh dan mengurus beberapa santri, dibutuhkan latihan dan konsistensi dalam menumbuhkan kesadaran pengasuhan. Apabila peran dan tugas tersebut dijalankan sesuai dengan kesadaran pengasuhan, maka optimalisasi dalam mengembangkan potensi serta pemberian solusi dan arahan dalam menyelesaikan tugas perkembangan santri dapat berjalan dengan baik. ${ }^{25}$ Sama halnya orang tua, tugas seorang pengurus dalam menerapkan pola asuh di pesantren ialah memantau perkembangan fisik maupun psikis, mengawasi setiap kegiatan yang ada dalam pesantren, memberi solusi dalam berbagai aspek permasalahan yang dialami santri serta mengarahkan dan membina akblak karimah yang menjadi pokok tujuan dari visi misi sebuah pesantren. Terlatihnya sebuah keterampilan dalam mengasuh serta mengawasi seluruh aspek perkembangan santri sejak berada dalam pesantren, menjadi bekal bagi setiap pengurus ketika menempuh kehidupan rumah tangga di masa mendatang. ${ }^{26}$ Untuk itu, seorang pengurus diharapkan mampu melatih dan mengembangkan keterampilan dalam mengasuh santri dengan sebaik-baiknya.

\section{Sistem Pola Asuh di Pesantren Nurul Jadid Sistem Pola Asuh}

Dalam pengaturan lembaga pesantren, Pondok Pesantren Nurul Jadid memiliki sistem yang cukup baik untuk mencapai tujuan dari visi misi pesantren. Visi menciptakan santri yang sadar akan tujuan mondok untuk mengaji dan membina akhlak al-karimah memerlukan sistem yang baik dalam pengasuhan dan bimbingan santri. Oleh karena itu, pesantren Nurul Jadid memanfaatkan program wali asuh untuk mencapai tujuan tersebut.

Berangkat dari banyaknya santri yang mencapai ratusan bahkan ribuan, pengoptimalisasian seluruh aspek perkembangan santri dilakukan dengan adanya wali asuh yang dapat mengontrol santri. Wali asuh sebagai pengganti dari peran kyai dalam

\footnotetext{
${ }^{23}$ Umar Mansyur \& Syafiqah Adimmah, Character Building Melalui Pendekatan Collaborative Authoritativerian Parenting, (Probolinggo: Pustaka Nurja, 2019), 10.

${ }^{24}$ Masyitoh, "Habituasi Peserta Didik Melalui Program Wali Asuh dalam Membentuk Karakter Santri Di Pondok Pesantren “, HIKMAH (jurnal pendidikan islam), 7, no. 2, (2018).

${ }^{25}$ Sri Lestari, PSIKOLOGI KELUARGA: Penanaman Nilai Dan Penanganan Konflik Dalam Keluarga, hlm. 36 .

${ }^{26}$ Hasan Baharun dan Madinatul Jannah. "Smart Parenting dalam Mengatasi Social Withdrawal pada Anak di Pondok Pesantren”, TA'ALLUM: Jurnal Pendidikan Islam, 7, no1, (2019), 45-72.
} 
pengasuhan beberapa santri berperan penting dalam keseharian santri sebagai sosok sementara seorang pengasuh selama kurun waktu belajar di pesantren. Selain sebagai bentuk ide pembaharuan di pesantren, penerapan sistem kewaliasuhan ini guna mengoptimalkan efektifitas kegiatan serta memudahkan pemantauan dan pengontrolan aspek psikis santri secara individu. ${ }^{27}$

Kebutuhan santri selama berada dalam lingkungan pesantren menjadi hal yang harus dilayani dengan penuh tanggung jawab dan keikhlasan oleh wali asuh, baik dalam masalah yang terait dengan nila-nilai kesantrian maupun pemahaman tentang furudbul 'ainiyah dan amaliyahnya. ${ }^{28}$ Tugas sebagai wali asuh dimulai sejak dititipkannya seorang anak oleh orang tuanya agar dapat dibimbing dan dibina untuk menjadi manusia yang memiliki kepribadian mulia dan khazanah keislaman yang luas.

Wali asuh di wilayah Az-Zainiyah Pondok Pesantren Nurul Jadid memiliki satuan tugas yang harus dipenuhi. Satuan tugas tersebut sebagai rujukan bagi wali asuh dalam menjalankan dan menerapkan bagaimana sistem pola asuh di pesantren. Sebagai wakil atau pengganti dari orang tua, wali asuh membutuhkan pembelajaran dan pelatihan pola asuh bagaimana menjadi seorang pengasuh yang tidak hanya bertugas mengontrol kegiatan santri melainkan juga memperhatikan aspek perkembangan fisik maupun psikis seorang santri.

Sebagai wali asuh yang masih aktif menjadi santri membutuhkan waktu untuk belajar mengayomi dan memberi kasih sayang kepada santri. Dari itu, perlu dilakukan sebuah pendekatan. Startegi pendekatan yang dilakukan oleh wali asuh dapat dimulai dengan menjaga komunikasi baik kepada santri. ${ }^{29}$ Semisal, memberi panggilan sayang kepada santri yang dapat menimbulkan respon baik kepada wali asuh sehingga mereka memiliki kedekatan dan menganggap wali asuh sebagai orang yang benar-benar dipercaya mampu membimbingnya. Setelah wali asuh mendapat kepercayaan dari santri, hal tersebut akan berdampak kepada kedekatan yang akan memudahkan wali asuh dalam memantau perkembangan yang terjadi dalam diri santri.

Ada empat tanggung jawab pengasuhan yang dibebankan pada seorang wali asuh yakni: pertama, wali asuh bertanggung jawab penuh terhadap aspek perkembangan santri, kedua, wali asuh memberikan layanan bimbingan dan konseling kepada santri, ketiga, wali asuh melakukan koordinasi jika mendapati masalah yang sulit ditangani sendiri, keempat, wali asuh wajib memberi laporan setiap minggu kepada pengurus bagian BK (Bimbingan dan Konseling) terkait perkembangan anak asuh. Aspek perkembangan santri yang harus diperhatikan oleh wali asuh meliputi: kemampuan baca tulis Al-Qur'an, pemahaman furudhul 'ainiyah dan amaliyahnya, perkembangan akhlakul karimah, perkembangan motivasi belajar, dan aspek kebersihan yang mencakup kebersihan diri sendiri ataupun lingkungan sekitarnya ${ }^{30}$.

Untuk mengasah kemampuan membaca dan menulis Al-Qur'an, santri diberi pembinaan langsung tiap selesai jamaah sholat subuh dan sholat maghrib, beda halnya dengan pembinaan yang dilakukan dalam rangka mengembangkan dan mengasah

${ }^{27}$ Alfi Najmatil Ilmy et al., "Pendidikan Di Pesantren", Journal of Islamic Education Studies, 6, no. 1 (2018) 45.

${ }^{28}$ Saifur Rizal, "Servant Leadership dalam Implementasi Nila-Nilai Trilogi dan Panca Kesadaran Santri”, Evaluasi, Journal Staima-al-bikam, 3, no. 2, (2019) 2615-2886.

${ }^{29}$ Alfi Najmatil, Hamid, Chusnul, "Urgensi Keterlibatan Wali Asuh Dalam Dinamikan Pendidikan di Pesantren", Journal of Islam Education Studies, 6, no. 1, (2018), 44-66.

${ }^{30}$ Wawancara kepada Ustadzah Ida Rosita (Ketua Bagian BK/WA Wilayah Az-Zainiyah), pada tanggal 14 Desember 2019. 
kemampuan furudhul 'ainiyah, wali asuh biasa memberikan pembinaan sekaligus materi tiap satu minggu sekali. Usaha wali asuh dalam mendidik santri agar menjadi manusia yang mempunyai perilaku luhur ialah dengan melakukan pembiasaan-pembiasaan baik yang dimulai dari hal terkecil. Contohnya, pembiasaan santri menerapkan 3S (senyum, salam, sapa) ketika bertemu dengan teman ataupun pengurus. Pembiasaan tersebut akan menjadi satu hal yang berdampak pada karakter baik seorang santri.

Pengontrolan aspek kognitif ataupun afektif santri dilakukan oleh wali asuh sebagai bentuk evaluasi agar wali asuh mengetahui sejauh mana perkembangan santri. Dengan itu, wali asuh bisa dengan mudah membantu, membimbing dan membina santri dalam mengembangkan potensi yang ada dalam dirinya. Sebagai wali asuh yang diberi tanggung jawab pengasuhan, wali asuh dituntut untuk menjadi manusia yang multi talent sebagaimana peran orang tua dalam mengasuh anaknya. Salah satu perannya juga sebagai konselor Islam, dimana konselor dalam pandangan Islam memiliki beberapa kriteria, diantaranya: Pertama, mempunyai penguasaan materi yang cukup baik terkait keilmuan agama Islam. Kedua, mengamalkan dengan baik dan konsekuen nilainilai agama Islam. Ketiga, memaksimalkan kemampuan mentransfer kaidah-kaidah Islam secara garis besar kepada klien. Keempat, menguasai beberapa metode dan strategi yang tepat untuk menyampaikan bimbingan dan konseling kepada klien, sehingga konselor dengan mudah memberi nasehat kepada klien. Kelima, memiliki pribadi luhur yang dapat dijadikan teladan dalam berperilaku baik di dalam ataupun diluar tempat bekerja. Keenam, menguasai bidang konseling secara integral. ${ }^{31}$

Dari beberapa kriteria konselor Islam, wali asuh dituntut memaksimalkan keterampilannya agar bisa menjadi konselor yang baik bagi santri. Peran sebagai seorang konselor sangat dibutuhkan guna memberikan layanan secara penuh dalam aspek dasar, pribadi, keluarga, sosial, karier, belajar, dan responsif (layanan konsultasi dan konseling) kepada santri. Dengan adanya layanan bimbingan dan konseling ini, santri diharapkan memiliki pengarahan dalam mencapai tujuan untuk mengoptimalkan potensi baik yang ada dalam dirinya. Sebagai pengganti yang dipercaya untuk mengasuh beberapa santri, kinerja wali asuh tidak akan lepas dari sebuah pengawasan jajaran pengasuh. Untuk itu, wali asuh diberi peluang untuk melakukan koordinasi dengan beberapa pihak diantaranya, BK daerah, kepala daerah, BK wilayah, serta pemangku wilayah. Koordinasi tersebut dilakukan dalam rangka menyelesaikan masalah yang terjadi pada santri yang tidak menemukan solusi penyelesaiannya.

Koordinasi yang dilakukan oleh wali asuh memiliki prosedur dan tahapan tersendiri, melihat posisi wali asuh yang berada tepat dibawah naungan dan wewenang pengurus BK wilayah dan BK daerah. Penyelesaian masalah yang tidak dapat diatasi, terlebih dahulu dikoordinasikan kepada BK daerah. Kemudian, apabila masih belum menemukan solusi, maka BK daerah melakukan koordinasi dengan pihak BK wilayah terkait bagaimana penanganan dan penyelesaian masalah yang terjadi pada santri.

Selain terkait beberapa masalah yang membutuhkan penanganan langsung dari BK wilayah, pengkoordinasian antara wali asuh, BK daerah, dan BK wilayah dilakukan sabagai wadah untuk mengevaluasi sejauh mana perkembangan anak asuh dan kendala yang terjadi selama satu pekan. Hasil dari evaluasi yang dilakukan setiap satu minggu 
sekali, kemudian dilaporkan kepada segenap jajaran pengasuh yang memegang penanganan BK khususnya program kewaliasuhan. ${ }^{32}$

Terkait pelaporan tentang beberapa aspek perkembangan santri, wali asuh diharuskan melaporkan secara tertulis pada media penilaian yang disebut pedatren. Program pedatren yang dibuat oleh pihak pesantren dikhususkan kepada wali asuh guna mencatat beberapa aspek perkembangan santri secara individu. Adapun pelaporan yang dituliskan terkait dengan perkembangan aspek afektif dan kognitif seorang santri. Dalam aspek afektif yang dilaporkan meliputi perkembangan akhlak, kepedulian, dan kebersihan. Sedangkan dalam aspek kognitif meliputi perkembangan baca tulis Al-Qur'an, furudhul 'ainiyah, bacaan kitab kuning, hafalan/ tahfidz, dan kebahasaan.

Dari beberapa poin dalam aspek kognitif, tidak semua poin ditulis oleh wali asuh. Karena, ada beberapa poin yang hanya diisi oleh wali asuh yang berada di kelembagaan wilayah. Dimana untuk poin bacaan kitab kuning, diisi oleh wali asuh yang memiliki anak asuh (santri) yang berada di lembaga kajian kitab kuning. Sedangkan, untuk poin hafalan/tahfidz diisi oleh wali asuh yang berada di lembaga PPIQ (Pusat Pendidikan Ilmu Al-Qur'an). ${ }^{33}$ Aspek perkembangan afektif dan kognitif santri dimaksudkan sebagai bukti tertulis yang dapat dipantau secara langsung maupun tidak langsung oleh jajaran pengasuh, sehingga jajaran pengasuh juga dapat memberikan solusi jika ada santri yang memiliki permasalahan yang cukup berat.

Berbicara mengenai pola asuh yang dilakukan oleh wali asuh, aspek yang terpenting dalam pola asuh adalah penerimaan dan pengontrolan. Penerimaan adalah segala bentuk dukungan dan kasih sayang yang diberikan kepada santri, Sedangkan kontrol adalah pengawasan terhadap aktivitas santri. Sudah menjadi tugas dasar bagi wali asuh untuk selalu memberikan dukungan dan pengarahan terhadap keputusan yang dipilih oleh santri serta pengawasan dan pengontrolan terhadap keseluruhan kegiatan santri. ${ }^{34}$ Untuk menyeimbangkan antara kontrol dan penerimaan yang cukup tinggi, wali asuh dapat menerapkan pola asuh otoritatif atau demokratis pada santri. Pola asuh otoritatif memiliki karakteristik hangat namun tetap tidak menghilangkan kesan tegas ketika mendidik. Untuk itu, penerimaan wali asuh terhadap keputusan maupun pendapat santri dilakukan secara musyawarah bersama dengan pihak yang terkait dalam pengasuhannya. Selain itu, wali asuh juga dapat mengontrol serta mengawal santri dengan tetap memberikan peluang besar dan tidak membatasi santri dalam mengembangkan potensi yang ada dalam dirinya. ${ }^{35}$

Apabila pola asuh otoritatif ini diterapkan dalam sistem kewaliasuhan, maka wali asuh dalam melakukan musyawarah tidak hanya melibatkan setiap komponen yang ada di dalam pesantren, namun orang tua santri juga diberi peluang atau kesempatan untuk menyampaikan keluhan dan pendapat bagi pertumbuhan dan perkembangan anaknya selama belajara di pesantren. Dalam hal ini, sistem pola asuh di pesantren memiliki relevansi yang cukup baik dengan tripusat pendidikan ajaran Ki Hajar Dewantara yang

\footnotetext{
${ }^{32}$ Wawancara kepada Ustadzah Ida Rosita (Ketua Bagian BK/WA Wilayah Az-Zainiyah), pada tanggal 14 Desember 2019.

${ }^{33}$ Wawancara kepada Ustadzah Nikmatul Maghfiroh (Kepala Wilayah Az-Zainyah), pada tanggal 26 Desember 2019.

${ }^{34}$ Alfi Najmatil, Hamid, Chusnul, "Urgensi Keterlibatan Wali Asuh Dalam Dinamikan Pendidikan di Pesantren", Journal of Islam Education Studies, 6, no. 1, (2018), 44-66.

${ }^{35}$ Umar Mansyur \& Syafiqah Adimmah, Character Building Melalui Pendekatan Collaborative Authoritativerian Parenting, 33.
} 
terdiri dari lingkungan keluarga yakni tempat asal santri, lingkungan perguruan atau lembaga (sekolah) dan lingkungan masyarakat yang tercermin dalam kehidupan pesantren menjadi hal yang sangat mendukung dalam proses pendidikan. Dengan melibatkan seluruh aspek lingkungan santri maka pendidikan akan dengan mudah diterima oleh santri. ${ }^{36}$

\section{Implementasi Kewaliasuhan di Pesantren Nurul Jadid}

Keberadaan wali asuh dalam poros kehidupan di Pondok Pesantren Nurul Jadid membawa dampak yang cukup signifikan dikarenakan perannya dalam mendidik, membina, mengarahkan, mengontrol, dan memantau seluruh perkembangan santri serta menjadi teladan bagi santri. Adanya program wali asuh yang diterapkan di Pondok Pesantren Nurul Jadid memiliki dampak positif dan negatif karena tidak semua sistem selalu berjalan dengan sempurna. Penerapan program kewaliasuhan ini, memiliki dampak positif bagi wali asuh sendiri, pesantren dan kalangan santri. Hal tersebut memicu kelayakan program kerja yang dimiliki oleh pesantren dan berpotensi untuk terus dijalankan dan dikembangankan guna mencapai tujuan pokok dari visi misi pondok pesantren sebagaimana tercermin dalam prinsip trilogi santri dan panca kesadaran santri.

Bagi santri yang diberi tanggung jawab menjadi wali asuh, program tersebut dapat menjadi ladang latihan untuk menjadi ibu yang baik dan mengasah keterampilan menjadi seorang pengasuh bagi anak-anaknya kelak. Dalam pelaksanaan tanggung jawab menjadi seorang wali asuh, pihak pesantren tidak serta merta menanggungkan tugas kewaliasuhan begitu saja kepada wali asuh. Sebelum menjadi wali asuh, seorang santri yang dipilih untuk mengasuh santri diberi pelatihan-pelatihan terkait kewaliasuhan, seperti halnya pelatihan bagaimana cara menjadi wali asuh yang dapat diterima keberadaanya oleh santri dan pelatihan BK (Bimbingan dan Konseling). ${ }^{37}$

Dampak implementasi dari program wali asuh bagi pesantren sendiri ialah meningkatnya efektifitas pengontrolan kegiatan santri secara menyeluruh, karena setiap santri telah memiliki wali asuh yang siap membimbing, mengarahkan, mendidik dan mengontrol kegiatan dan perkembangnya. Setiap wali asuh diberi tanggungan pengasuhan sekitar 7 sampai 10 santri, sehingga satu orang wali asuh hanya fokus bertugas pada santri yang berada dibawah tanggungannya. Tidak hanya itu, dampak positif lainnya ialah bagi kalangan santri, dimana santri memiliki tempat untuk sharing berbagai permasalahan yang dialaminya, sehingga santri mendapatkan solusi baik dalam menyelesaikan masalahnya. Seorang wali asuh dituntut menjadi pendengar yang baik dan pemberi nasehat yang bijak, sebagaimana wali asuh harus bisa menjadi sosok ibu, teman sebaya, sahabat, motivator, konselor serta guru disetiap keadaan santri.

Terealisasinya program wali asuh di lingkungan Pondok Pesantren Nurul jadid tidak hanya memiliki dampak positif, dampak negatif pun juga menjadi hal yang harus di jadikan bahan evaluasi bagi beberapa pihak yang terkait. Hal ini berlaku bagi wali asuh yang juga menjabat sebagai pengurus. ${ }^{38}$ Sebagai seorang santri yang memiliki tanggungan atas dirinya sendiri, meraka juga memiliki dua tanggung jawab yang samasama membutuhkan prioritas. Butuh waktu ekstra dan manajemen waktu yang baik

\footnotetext{
${ }^{36}$ Ibid, 29.

${ }^{37}$ Wawancara kepada Ustadzah Ida Rosita (Ketua Bagian BK/WA Wilayah Az-Zainiyah), pada tanggal 14 Desember 2019.

${ }^{38}$ Alfi Najmatil, Hamid, Chusnul, "Urgensi Keterlibatan Wali Asuh Dalam Dinamikan Pendidikan di Pesantren", 2527-4511.
} 
untuk menjalankan tugas-tugas tersebut agar dapat mencapai tujuan dengan baik. Namun, melihat kenyataan yang terjadi di lapangan, tidak sedikit dari santri yang mempunyai tugas ganda sebagai wali asuh sekaligus pengurus mengalami penumpukan kegiatan yang tidak terlaksana, sehingga hal tersebut mengakibatkan tidak terkontrolnya kegiatan santri secara optimal.

Selain itu, tidak sedikit dari para santri senior yang menjadi seorang wali asuh kurang memiliki kesadaran dan kedekatan kepada santri, sehingga mereka hanya mampu melihat perkembangan santri dari segi fisiknya saja, tidak dalam segi psikisnya. Sebab itu, perlu adanya kepekaan dari seorang wali asuh terhadap lingkungan sekitarnya. Tidak hanya itu, dampak yang kurang menguntungkan ialah terjadi dalam lingkungan santri sendiri. Dimana, dalam satu kamar terkadang ada dua sampai lima wali asuh yang ditugaskan untuk memegang kepengasuhan santri. Hal tersebut, mengakibatkan adanya pemisah dalam hal pengayoman keseluruhan santri dalam satu kamar. Semisal, ketika satu orang santri sedang sakit, maka wali asuh yang tidak memegang kepengasuhannya cenderung sukar dan canggung untuk mengurusinya sebelum wali asuh dari santri tersebut yang menanginya terlebih dahulu. ${ }^{39}$ Melihat beberapa dampak positif dan negatif yang terjadi di lapangan, menjadi bahan evaluasi bagi pihak pesantren untuk terus membenahi sistem kinerja wali asuh agar dapat mencapai tujuan awal dari visi misi pesantren dengan baik.

\section{Simpulan}

Berdasarkan pemaparan diatas, dapat ditarik kesimpulan bahwa implementasi dari sistem kewaliasuhan menjadi hal yang sangat signifikan bagi kehidupan masyarakat pesantren. Hal tersebut dikarenakan peran wali asuh yang memberikan kontribusi besar dalam upaya pengoptimalisasian dan pengontrolan seluruh aspek yang terkait dengan perkembangan santri, baik dalam segi afektif maupun kognitif santri secara personal. Sistem pola asuh yang diterapkan di wilayah Az-Zainiyah Pondok Pesantren Nurul Jadid ini, bertujuan untuk mensukseskan program kerja pesantren dan pencapaian tujuan pesantren dalam mewujudkan santri yang mempunyai akhlakul karimah dan memiliki khazanah keilmuan yang luas.

Eksistensi sistem kewaliasuhan membutuhkan adanya kesadaran pengasuhan dari seorang wali asuh sendiri, karena perannnya dalam berbagai hal yang terkait dengan santri, baik dalam hal pemahaman khazanah keislaman, budaya religius yang mewujudkan kepribadian luhur, serta pendidikan yang berfungsi untuk memanusiakan manusia.

Untuk menumbuhkan kesadaran pengasuhan, wali asuh diharapkan selalu mengadakan pertemuan dengan seluruh santri (anak asuh) setidaknya satu minggu satu kali, sekedar mengevaluasi ataupun berbagi cerita tentang kegiatan santri selama satu pekan sebelumnya. Jika pertemuan dilakukan secara konsisten, maka hal tersebut akan menumbuhkan kedekatan emosional antara wali asuh dengan santri tanpa disadari.

Seorang wali asuh dapat menggunakan metode authoritative parenting dalam mendidik santri, karena pola asuh tersebut sangat mengutamakan musyawarah mufakat dalam menentukan dan memberi keputusan yang baik bagi perkembangan santri dengan tetap menghargai pendapat dari seorang santri untuk mengembangkan potensi dirinya sendiri. Pola asuh ini melibatkan tripusat pendidikan dalam mendidik santri,

${ }^{39}$ Wawancara kepada Risma Aula Nisa (sala satu wali asuh di wilayah A-Zainiyah), pada tanggal 27 Desember 2019. 
sehingga santri lebih terarah dan mendapat dukungan lebih dalam menjalani proses pembelajaran di pesantren

\section{Daftar Pustaka}

Adimmah, Umar, Mansyur dan Syafiqah, (2019). Character Building Melalui Pendekatan Collaborative Authoritativerian Parenting, Probolinggo: Pustaka Nurja.

Amin, Samsul Munir, (2010). Bimbingan dan Konseling Islam, Jakarta: Amzah.

Baharun, Hasan, (2017).'Total Moral Quality: A New Approach for Character Education in Pesantren", Jurnal Ulumuna 21, no. 1.

Bariroh, Akmal Mundiri dan Afidatul, (2018). "Trans Internalisasi Pembentukan Karakter Melalui Trilogi Santri dan Panca Kesandaran Santri”, IQRA' Jurnal Kajian Ilmu Pendidikan), 3, no.1.

Dhofier, Zamakhsyari, (2015). Tradisi Pesantren: Studi Pandangan Hidup Kyai dan Visinya Mengenai Masa Depan Indonesi, Jakarta: LP3ES.

Djamarah, Saiful Bahri, (2014). Pola Asub Orang tua dan Komunikasi dalam Keluarga upaya membangun Citra Membentuk Pribadi Anak, Jakarta: Rineka Cipta.

Hasbullah, (1999). Sejarah Pendidikan Islam di Indonesia, Jakarta: LKIS

Ilahi, Muhammad Takdir, (2013). Quantum Parenting, Jogjakarta: Ar-Ruzz Media.

Ilmy, Abdul Hamid, Chusnul Muali dan Alfi Najmatil, (2018). "Urgensi Keterlibatan Wali Asuh Dalam Dinamikan Pendidikan di Pesantren", Journal of Islam Education Studies, 6, no. 1.

Ilmy, Alfi Najmatil et al., (2018). "Pendidikan Di Pesantren”, Journal of Islamic Education Studies, 6, no. 1.

Jannah, Hasan Baharun dan Madinatul, (2019). "Smart Parenting dalam Mengatasi Social Withdrawal pada Anak di Pondok Pesantren", Ta'allum: Jurnal Pendidikan Islam, 7, no1.

Lestari, Sri, (2012). Psikologi Keluarga: Penanaman Nilai Dan Penanganan Konflik Dalam Keluarga, Jakarta: Prenamedia Group.

Lubis, Rafiqatul Hamidiyah, (2018). "Metode Parenting Pembentukan Sikap di Pondok Pesantren Modern Darussalam Kepahiang, Bengkulu”, (Skripisi Program Sarjana Sosial, Institut Agama Islam Negeri Bengkulu.

Masyitoh, (2018). "Habituasi Peserta Didik Melalui Program Wali Asuh dalam Membentuk Karakter Santri Di Pondok Pesantren ", HIKMAH (jurnal pendidikan islam), 7 , no. 2 .

Muali, Asiatik Afrik R, Abdul Hamid, Chusnul, (2017). "Smart Parenting Demokratis Dalam Membangun karakter Anak". Al-Athfal Jurnal Pendidikan Anak. 4, no.1.

Muali, Chusnul, (2017). "Rasionalitas Konsepsi Budaya Nusantara dalam Menggagas Pendidikan Karakter Bangsa Multikultural," Jurnal Islam Nusantara 1, no. 1.

Muallifah, (2009). Psycho Islamic Smart Parenting, Jogjakarta: Deva Press.

Nata, Abuddin, (2001). Sejarah Pertumbuban dan Perkembangan Lembaga-Lembaga Pendidikan Islam di Indonesia, Jakarta: Grasindo.

Nur Hidayat, Asmuji, \& Walid. "Hubungan Pola Asuh Wali Kamar Dengan Tingkat Kemandirian Adl (Activity Of Daily Living) Santri Usia Sekolah Di Pondok Pesantren Anak-Anak Dan Tahfidzul Qur'an Al-Qodiri Jember", http:// fikes.unmuhjember.ac.id, (diakses 17 Desember 2019). 
Rizqi, Amalina, (2016). "Hubungan Pola Asub Pondok Pesantren dengan Pembentukan Karakter Santriwati (Studi Kasus di Pondok Pesantren Ta'mirul Isalam Surakarta)", Skripsi Program Sarjana Pendidikan, Institut Agama Islam Negeri Salatiga.

Sekretariat PP Nurul Jadid, (2019). Selayang Pandang Pondok Pesantren Nurul Jadid. Paiton: Bagian Humas dan Protokuler Sekretariat PondokPesantren Nurul Jadid. Ummah, Hasan Baharun dan Rohmatul, (2018). "Strengthening Student's Character in Akhlaq Subject Through Problem Based Learning Model”. Tadris: Jurnal Keguruan Dan Imu Tarbiyah 3, no. 1.

Zuhry, Dhofir, (2019). Peradaban Santri, Jakarta: PT. Gramedia.

Zulhimma, (2013). "Dinamika Perkembangan Pondok Pesantren di Indonesia", Darul 'Imi 1, no. 2. 